\title{
JURNAL REDOKS
}

Pelindung

Muhammad Firdaus,S.T,M.T

(Dekan Fakultas Teknik Universitas PGRI Palembang)

\author{
Pengarah \\ Ir.M. Saleh Al Amin,M.T (Wakil Dekan I) \\ Adiguna,S.T,M.Si ( Wakil Dekan II) \\ Aan Sefentry,S.T,M.T ( Wakil Dekan III) \\ Pimpinan Editorial \\ Husnah ,S.T,M.T \\ Dewan Editorial \\ Ir.Muhammad Bakrie,M.T \\ Muhrinsyah Fatimura,S.T,M.T \\ Rully Masriatini,S.T,M.T \\ Nurlela,S.T,M.T \\ Marlina,S.T,M.T \\ Reno Fitrianti,S.T,M.Si \\ Andriadoris Maharanti,S.T,M.T \\ Ir.Agus Wahyudi.M.M
}

\section{Mitra Bestari}

Dr.Erfina Oktariani,S.T,M.T ( STMI Kementerian Perindustrian RI)

Dr.Rer.nat. Risfidian Mohadi, S.Si., M.Si (Universitas Sriwijaya).

Dr. Eko Ariyanto, M.Eng, Chem (Universitas Muhamadiyah Palembang)

Daisy Ade Riany Diem, ST., MT. (Sekolah Tinggi Teknologi Wastukancana)

\section{Staff Editor}

Endang Kurniawan,S.T

Yuni Rosiati,S.T

\section{Alamat Redaksi :}

Program Studi Teknik Kimia Universitas PGRI Palembang

Jalan Jend. A. Yani Lorong Gotong Royong 9/10 Ulu Palembang Sumatera Selatan

Telp. 0711-510043 Fax. 0711-514782 e-mail : tekim.upgri@gmail.com 


\section{JURNAL REDOKS}

Volume 1, Nomor 2, Juli - Desember 2016

\section{DAFTAR ISI}

Artikel Penelitian

Halaman

1. Pengolahan Air Limbah Pewarna Sintetis Untuk Menurunkan Kadar COD Dan Warna Dengan Metode Adsorpsi. (Nurlela) .................................................. 1-5

2. Penurunan Kadar Fenol Dalam Limbah Cair Industri Tenun Songket Dengan Proses Elektrokoagulasi (Atikah) 6-15

3. Penerapan Produksi Bersih Pada Industri Pulp dan Kertas. (Reno Fitrianti)... 1625

4. Studi Pengaruh Proses Pengintegrasian Panas Terhadap Konversi Amoniak Pada Intercooler Reaktor Amoniak Pusri II Dengan Analisis Pinch. (Desy Rosarina) 26-34

5. Pembuatan Biodiesel Dari Minyak Jelantah Dengan Variasi Penambahan Katalis KOH Pada Proses Transesteriikasi. (Muhrinsyah Fatimura, Daryanti, Santi). 3543

6. Evaluasi Kinerja Filter Keramik Pada Pengolahan Air Sungai Musi Berdasarkan Fluks Membrane. (Husnah). 44-49

7. Pengaruh Waktu Dan Massa Zat Asam Benzoate Terhadap Kadar Vitamin C Dalam Pembuatan Sirup Mangga. (Rully Masriantini) 50-55

Petunjuk Untuk Penulisan .$i i i$

Daftar Pustaka .$i v$ 


\title{
Petunjuk Untuk Penulis
}

\section{A. Naskah}

Naskah yang diajukan oleh penulis harus diketik dengan komputer menggunakan bahasa Indonesia yang baik dan benar, menyertakan 1 (satu) soft copy dalam bentuk CD. Penulisan memakai program Microsoft Word dengan ukuran kertas A4, jarak 1,15 spasi.

Naskah yang diajukan oleh penulis merupakan naskah asli yang belum pernah diterbitkan maupun sedang dalam proses pengajuan ditempat lain untuk diterbitkan, dan diajukan minimal 1 (satu) bulan sebelum penerbitan.

\section{B. Format Penulisan Artikel \\ Judul}

Judul ditulis dengan huruf besar, nama penulis tanpa gelar, mencantumkan instansi asal, email dan ditulis dengan huruf kecil menggunakan huruf Times new Roman 11.

\begin{abstract}
Abstrak
Abstrak ditulis dalam bahasa Indonesia antara 100-250 kata, dan berisi pernyataan yang terdapat dalam isi tulisan, menyatakan tujuan dari penelitian, prosedur dasar (pemilihan objek yang diteliti, metode pengamatan dan analisis), ringkasan isi dan kesimpulan dari naskah menggunakan huruf Time New Roman 11, spasi 1,15.

\section{Kata Kunci}

Minimal 3 (tiga) kata kunci ditulis dalam bahasa Indonesia

\section{Isi Naskah}

Naskah ditulis menggunakan huruf Times New Roman 11. Penulisan dibagi dalam 5 (lima) sub judul, yaitu Pendahuluan, Kajian Pustaka, Metode Penelitian, Hasil Pembahasan dan Kesimpulan. Penulis menggunakan standar Internasional (misal untuk satuan tidak menggunakan feet tetapi meter, menggunakan terminalogi dan simbol diakui international (Contoh hambatan menggunakan simbol R). Bila satuan diluar standar SI dibuat dalam kurung $($ misal $=1$ Feet $(\mathrm{m})$ ). Tidak menulis singkatan atau angka pada awal kalimat, tetapi ditulis dengan huruf secara lengkap, Angka yang dilanjutkan dengan simbol ditulis dengan angka Arab, misal 3cm, 4kg. Penulis harus secara jelas menunjukkan rujukan dan sumber rujukan secara jelas.
\end{abstract}

\section{Daftar Pustaka}

Rujukan / Daftar pustaka ditulis dalam urutan angka, tidak menurut alpabet, dengan ketentuan 
seperti dicontohkan sbb :

1. Standar Internasional :

IEC 60287-1-1 ed2.0; Electric cables - Calculation of the current rating - Part 1 - 1: Current rating equations (100\% load factor) and calculation of losses - General. Copyright (C) International Electrotechnical Commission (IEC) Geneva, Switzerland, www.iec.ch, 2006

2. Buku dan Publikasi :

George J Anders; Rating of Electric Power Cables in Unfavorable Thermal

Environment. IEEE Press, 445 Hoes Lane, Piscataway, NJ 08854, ISBN 0-471- 67909-7, 2005.

3. Internet :

Electropedia; The World's Online Electrotechnical Vocabulary.

http://www.electropedia.org, diakses 15 Maret, 2011.

Setiap pustaka harus dimasukkan dalam tulisan. Tabel dan gambar dibuat sesederhana mungkin. Kutipan pustaka harus diikuti dengan nama pengarang, tahun publikasi dan halaman kutipan yang diambil. Kutipan yang lebih dari 4 baris, diketik dengan spasi tunggal tanpa tanda petik. 


\title{
PEMBUATAN BIODIESEL DARI MINYAK JELANTAH BEKAS RUMAH MAKAN DENGAN VARIASI PENAMBAHAN KATALIS KOH PADA PROSES TRANSESTERIFIKASI
}

\author{
Muhrinsyah Fatimura, Daryanti, Santi \\ Dosen PNSD Fakultas Teknik Program Studi Teknik Kimia \\ Universitas Pgri Palembang \\ e-mail: Muhrinsyah.f@gmail.com
}

\begin{abstract}
ABSTRAK
Minyak bumi merupakan sumber energi terbesar digunakan diseluruh dunia saat ini. Pemanfaat minyak bumi yang berlebihan sebagai sumber energi menyebabkan cadangan minyak bumi mulai berkurang,seiring dengan peningkatan jumlah kendaraan bermotor terutama bahan bakar kendaraan seperti solar,bensin yang kesemuannya merupakan bahan bakar yang susah diperbaharui (unrenewable.) Biodisel merupakan bahan bakar alternatif yang menjanjikan yang dapat diperoleh dari minyak nabati maupun lemak hewan melalui transesterifikasi dengan alkohol. Minyak jelantah yang digunakan bekas minyak pengorengan rumah makan dimana proses pembuatan biodiesel menggunakan proses transesterifikasi dengan memvariasikan katalis KOH. Penelitian ini bertujuan untuk mengetahui proses produksibiodieseldan mengetahui karakterisitik biodiesel dimana dengan memvariasikan Konsentrasi Katalis $\mathrm{KOH} 1 \%, 2 \%, 3 \%, 4 \%$ maka didapat Variasi penambahan katalis mempengaruhi nilai FFA dan Angka Asam yang didapat biodiesel, semakin banyak katalis nilai FFA dan AA biodiesel akan semakin kecil. Variasi penambahan katalis mempengaruhi nilai densitas yang didapat biodiesel, semakin banyak katalis maka densitas yang diperoleh akan lebih kecil. Dari variasi berbagai katalis $\mathrm{KOH}$, diperoleh bahwa kondisi optimum untuk penelitian ini adalah $4 \%$ katalis dari berat minyak. dimana didapat $F F A=0,2 \%, A A=0,27 \%$, Densitas $=0,859^{\mathrm{g}} / \mathrm{ml}$
\end{abstract}

Kata kunci : transesterifikasi, biodiesel, katalis.

\section{PENDAHULUAN}

Minyak bumi merupakan sumber energy terbesar digunakan diseluruh dunia saat ini. Pemanfaat minyak bumi yang berlebihan sebagai sumber energi menyebabkan cadangan minyak bumi mulai berkurang, seiring dengan peningkatan jumlah kendaraan bermotor terutama bahan bakar kendaraan seperti solar, bensin yang kesemuannya merupakan bahan bakar yang susah diperbaharui (unrenewable.)

Biodisel merupakan bahan bakar alternatif yang menjanjikan yang dapat diperoleh dari minyak nabati maupun lemak hewan melalui transesterifikasi dengan alkohol. Biodisel menghasilkan polusi lebih sedikit dari bahan bakar minyak bumi.Selain itu, biodisel dapat digunakan tanpa modifikasi ulang mesin diesel. Biodiesel dikenal sebagai bahan bakar yang ramah lingkungan dan menghasilkan emisi gas buang yang relatif lebih bersih dibandingkan bahan bakar fosil.Biodiesel tidak beracun, bebas dari belerang, aplikasinya sederhana dan berbau harum (Haryahto, 2002). 
Produksi biodisel yang dikembangkan saat ini umumnya terbuat dari minyak tumbuhan (minyak kedelai, minyak canola, minyak sawit mentah), lemak hewan (sapi talow, lemak babi, lemak ayam) dan bahkan dari minyak jelantah.Minyak jelantah adalah minyak limbah yang berasal dari jenis minyak goreng seperti minyak jagung, minyak sayur,minyak samin. Minyak jelantah merupakan minyak tumbuhan yang sudah digunakan untuk menggoreng. Penggunaan minyak tumbuhan bekas sebagai bahan baku biodisel menjadi sangat dimungkinkan karena nilai ekonomis minyak bekas ini sudah turun dibanding minyak tumbuhan yang belum digunakan. Disamping itu, dengan sifat karsinogenik minyak bekas yang berbahaya bagi tubuh, proses pembuatan biodisel dari minyak goreng menjadi alternative penyelesaian masalah yang patut dipertimbangkan. Di Indonesia, pemanfaatan minyak jelantah masih kontraversial. Sampai saat ini sebagian minyak jelantah dari perusahaan besar dijual ke pedagang kaki lima dan kemudian digunakan untuk menggoreng makanan dagangannya dan sebagian lain dibuang begitu saja ke saluran pembuangan. Bila ditinjau dari komposisi kimianya, minyak jelantah mengandung senyawa-senyawa yang bersifat karsinogenik, yang terjadi selama proses penggorengan. Senyawa-senyawa itu sangat berbahaya bagi tubuh manusia. Sehingga muncul inovasi untuk memanfaatkan minyak jelantah menjadi biodiesel. Adapun Potensi Minyak jelantah yang dihasilakan hotel, restaurant dan warung-warung, industry pengolahan makanan, pedagang kaki lima sangat besar terlihat pada tabel dibawah ini

Tabel.1. Jumlah Penghasil Minyak Jelantah Indonesia tahun 2007

\begin{tabular}{|c|c|}
\hline $\begin{array}{c}\text { Sektor Penghasil } \\
\text { Minyak Jelantah }\end{array}$ & $\begin{array}{c}\text { Jumlah } \\
\text { (ton/tahun) }\end{array}$ \\
\hline Rumah Tangga & $305.050,14$ \\
\hline Industri Pengolahan Makanan & $2.079 .417,56$ \\
\hline Restauran \& Hotel & $1.502 .218,93$ \\
\hline Total & $3.886 .686,63$ \\
\hline
\end{tabular}

Sumber (Yulia,2011).

Berdasarkan potensi besarnya minyak jelantah yang ada di Indonesia, dapat dijadikan acuan untuk mensubsitusi akan kebutuhan bahan bakar dari fosil yang cukup tinggi yaitu mengolah minyak jelantah menjadi bahan bakar biodiesel (.I Gusti, 2014)

Proses pembuatan biodiesel dari minyak jelantah dapat dilakukan dengan reaksi cara beragam, diantaranya menggunakan katalis dasar untuk transesterifikasi, esterifikasi katalis asam, dan metode superkritis (Zhang et.al., 2003). Minyak jenis Diesel adalah bahan bakar yang paling banyak digunakan oleh masyarakat Indonesia (Prihandana et al., 2006). Oleh karena itu jika anda ingin mengurangi jumlah penggunaan Berasal dari bahan bakar fosil, maka caranya adalah mengurangi penggunaan bahan bakar diesel dengan beralih ke biodisel.

Biodisel telah diproduksi oleh transesterifikasi trigliserida (minyak nabati) menjadi metil ester dengan metanol menggunakan natrium atau kalium hidroksida dilarutkan dalam metanol sebagai katalis.Biodisel dapat diproduksi melalui reaksi antara minyak jelantah dengan alkohol menggunakan katalis homogen. Dalam penelitian ini, jenis alkohol yang digunakan adalah metanol sebagai alkohol derivatif yang memiliki berat molekul rendah sehingga kebutuhan untuk alkoholisis relatif lebih sedikit, lebih murah dan lebih stabil.Selain itu, reaksi daya lebih tinggi bila dibandingkan dengan etanol (Prihandana et al., 2006). Jadi reaksi untuk memproduksi biodisel disebut reaksi methanolisis. Katalis yang sering digunakan dalam pembuatan biodisel adalah katalis homogen. $\mathrm{KOH}$ dan $\mathrm{NaOH}$ sering digunakan dalam produksi biodisel sebagai katalis. Selain itu, katalis homogen dapat bereaksi dengan sabun membentuk asam lemak bebas. 


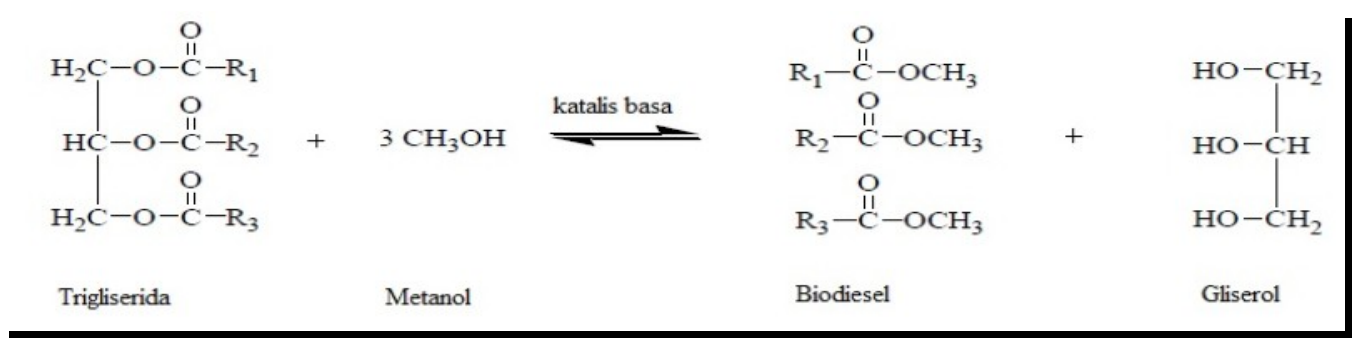

Gambar 1.Reaksi Transesterifikasi

Penelitian ini bertujuan Mengetahui bagaimana proses pembuatan biodiesel dari minyak jelantah bekas rumah makan dan sejauh mana pengaruh variasi penambahan katalis pada proses transesterifikasi pada perbandingan $\mathrm{KOH}$ katalis diantara minyak jelantah dan metanol dalam produksi biodiesel.

\section{METODE PENELITIAN}

Alat yang digunakan dalam penelitian ini adalah sebagai berikut:Corong pemisah ,Erlenmeyer ,Beaker gelas ,Labu reaksi Leher Dua,Kondenser,Corong,Pipet tetes,Termometer ,Magnetik Stirer,Neracabalance,Hotplate,Mortar porselen,Oven ,Batang pengaduk,Cawan,Piknometer ,Buret.Bahan yang digunakan dalam penelitian ini adalah sebagai berikut:Minyak Jelantah Limbah Rumah Makan,Methanol, $\mathrm{KOH}, \mathrm{Aquades}, \mathrm{H}_{2} \mathrm{SO}_{4}$, Indikator Phenolphthalein ,Ethanol.

\section{PELAKSANAAN PENELITIAN}

\section{Pembuatan Biodisel dari Minyak Jelantah Limbah Rumah Makan}

a. Esterifikasi (Pengurangan kadar FFA)

Minyak Jelantah Rumah Makan ditimbang di neraca Sartorius sebanyak 100 gram, kemudian dicampur dengan metanol pada rasio molar 18:01, 18 untuk metanol dan 1 untuk minyak. Katalis asam sulfat diambil 3\% dari berat minyak sebanyak $4,1 \mathrm{ml}$, tiga bahan dilarutkan dan campuran direfluks selama 1 jam pada suhu $50^{\circ} \mathrm{C}$ dengan menggunakan Magnetik Stirer, suhu dijaga sampai reaksi selesai. Setelah itu larutan dituang ke corong pisah untuk memisahkan metanol,sisa katalis, dan minyak. Larutan dibiarkan selama 24 jam untuk mendapatkan produk/ esterifikasi, hari berikutnya hasilnya bisa dilihat, minyak di bagian bawah produk dengan FFA telah berkurang dan yang terbentuk pada lapisan atas adalah metanol yang tidak bereaksi dan sisa asam sulfat. Buka valve corong pisah untuk memisahkan produk dari metanol dan asam sulfat yang berada pada lapisan atas.Lapisan atas tidak berguna sehingga kita hanya mengambil lapisan bawah (produk esterifikasi) untuk reaksi berikutnya.

\section{b. Penentuan Kadar Asam lemak bebas (FFA)}

Transesterifikasi tidak bisa menggunakan minyak sebagai bahan baku reaksi metanolisis dengan kadar asam lemak bebas $(>1 \%)$ karena akan menyebabkan reaksi saponifikasi,karena hal tersebut, pertama tama FFA harus dikurangi dengan reaksi esterifikasi. Dalam hal ini Titrasi telah dilakukan. Sebanyak 3 gr minyak ditimbang kemudian ditambahkan dalam $250 \mathrm{ml}$ Erlenmeyer dan juga etanol 98\% sebanyak $50 \mathrm{ml}$. Larutan kemudian ditambahkan 3 tetes indikator fenolftalein, lalu campuran dititrasi dengan $\mathrm{NaOH}$ 0,1M. Titrasi dilakukan sampai warna larutan berubah menjadi merah muda. Kemudian $\mathrm{NaOH}$ yang berkurang karena titrasi dicatat dan FFA dapat dihitung dengan persamaan ini (SNI 01-3555-1998) 
Keterangan :

$\begin{array}{ll}\mathrm{Mw}(\mathrm{fa}) & =\text { Berat Molekul Asam lemak dominan (Asam Palmitat) } \\ & 256,42 \mathrm{~g} / \mathrm{mol} \\ = & \text { Volume NaoH yang digunakan } \\ \mathrm{V} & =\text { Normalitas } \mathrm{NaOH}=0,1 \mathrm{M} \\ \mathrm{N} & =3 \mathrm{gr}\end{array}$

\section{c. Transesterifikasi}

Ambil $25 \mathrm{ml}$ methanol, masukan ke dalam labu Erlenmeyer yang berisi $\mathrm{KOH}$, aduk hati-hati sampai $\mathrm{KOH}$ larut hingga terbentuk K-metoksida.Setelah itu dicampur dilarutkan kedalam minyak yang telah diesterifikasi. Larutan di larutkan dan di refluks pada suhu $50^{\circ} \mathrm{C}$ dengan menggunakan Magnetik Stirer. Larutan dibiarkan selama 24 jam di dalam corong pisah untuk mendapatkan produk esterifikasi, hari berikutnya hasilnya bisa dilihat, lapisan bawah berupa gliserol dan lapisan atas berupa ester(biodiesel). Lakukan untuk sampel minyak dengan katalis $1 \%, 2 \%, 3 \%$, dan 4\%. Pengadukan untuk setiap sampel sama yaitu $600 \mathrm{rpm}$.

\section{d. Pemisahan Katalis, Pencucian, dan Pengeringan biodisel}

Ketika transesterifikasi selesai, gliserol dan katalis dipisahkan dari biodisel dengan membuka katup pada corong pemisah. Setelah zat pengotor dan katalis disaring, biodisel bersih akan diperoleh. Biodisel dimasukkan lagi ke dalam corong pemisah dan dicuci dengan aquades yang sebelumnya dipanaskan pada suhu sekitar $55-60^{\circ} \mathrm{C}$ dengan rasio $1: 1$ antara minyak dan air, pencucian dilakukan sebanyak 2 kali dan larutan didiamkan selama 5 jam. Akan terlihat sabun dan zat pengotor yang tersisa pada lapisan bawah, kemudian dipisahkan dari biodisel dan biodisel dikeringkan dalam oven dengan suhu sekitar $90^{\circ} \mathrm{C}$ selama 6 jam untuk menghilangkan air yang terkandung.

\section{Analisa Biodisel}

Pembuatan Biodisel yang telah melalui beberapa tahap dan menghasilkan produk akhir dalam bentuk cairan kuning jernih dengan viskositas lebih rendah daripada sebelumnya, kemudian sampel yang akan dianalisis dibuat 4 sampel dalam variasi katalis sesuai dengan prosedur. Parameter yang diuji adalah densitas, FFA Biodisel hasil dari transesterifikasi dan untuk mengukur angka Asam.

\section{a. Pengukuran FFA dan Angka Asam}

Kandungan FFA tinggi yang terkandung dalam biodisel tidak baik untuk produk biodisel, itu akan membuat angka Asam juga tinggi dan memberikan beberapa masalah mesin seperti kerusakan mesin disel. Dalam hal ini Titrasi dilakukan untuk mengukur FFA dan angka asam. Sebanyak $3 \mathrm{gr}$ minyak ditambahkan dalam $250 \mathrm{ml}$ Erlenmeyer dan juga etanol 98\% sebanyak $50 \mathrm{ml}$ ditambahkan. Larutan ditambah 3 tetes indikator fenolftalein, maka campuran dititrasi dengan $0,1 \mathrm{M} \mathrm{NaOH}$ dalam buret $25 \mathrm{ml}$. Titrasi telah selesai dilakukan jika warna larutan berubah menjadi merah muda.Setelah titrasi selesai $\mathrm{NaOH}$ yang habis digunakan diukur untuk menghitung FFA dengan persamaan ini (SNI 01-3555-1998).

$$
\operatorname{FFA}(\%)=\frac{M w(f a) \cdot V \cdot N}{10 \cdot m \text { oil }}
$$

\section{Keterangan :}

$$
\begin{aligned}
\mathrm{Mw}(\mathrm{fa}) & =\text { Berat molekul asam lemak dominan (Asam Palmitat) } \\
& 256,42 \mathrm{~g} / \mathrm{mol} \\
\mathrm{V} & \text { Volume NaoH yang digunakan }
\end{aligned}
$$




$$
\begin{array}{ll}
\mathrm{N} & =\text { Normalitas } \mathrm{NaOH}=0,1 \mathrm{M} \\
\mathrm{m} \text { oil } & =3 \mathrm{gr}
\end{array}
$$

Untuk pengukuran angka asam dapat dihitung dengan persamaan sebagai berikut:

$$
\% \text { FFAx } \frac{M w N a O H}{M w \text { Pal Acid }: 10}
$$

Keterangan :

$$
\begin{array}{ll}
\mathrm{Mw} \mathrm{NaOH} & =\text { Berat Molekul } \mathrm{NaOH}=39,9971 \mathrm{~g} / \mathrm{mol} \\
\mathrm{V} & =\text { Volume NaoH yang digunakan } \\
\mathrm{N} & =\text { Normalitas NaOH }=0,1 \mathrm{M} \\
\mathrm{Mw} \text { Pal Acid } & =\text { Berat Molekul asam Palmitat }=256,42 \mathrm{~g} / \mathrm{mol}
\end{array}
$$

\section{b. Pengukuran Densitas}

Prinsip kerja dari penentuan densitas adalah perbandingan massa contoh tanpa udara pada suhu dan volume tertentu dengan massa air pada suhu dan volume yang sama. Piknometer kosong dikeringkan di dalam oven kemudian ditimbang terlebih dahulu, lalu piknometer diisi dengan aquadest suhu $20^{\circ} \mathrm{C}$ kemudian disimpan dalam water bath pada suhu $25^{\circ} \mathrm{C}$ selama 30 menit.Diusahakan tidak ada gelembung-gelembung udara di dalam piknometer yang berisi aquadest maupun contoh.Piknometer kemudian diangkat, dikeringkan, dan ditimbang.Berat aquadest diperoleh dari selisih berat piknometer berisi aquadest dan berat piknometer kosong.Pada tahap selanjutnya sampel minyak didinginkan sampai suhu $20^{\circ} \mathrm{C}$.Kemudian minyak dimasukkan ke dalam piknometer yang sebelumnya telah dibersihkan dan dikeringkan hingga meluap dan tidak terbentuk gelembung udara.Bagian luar piknometer dikeringkan dan piknometer ditempatkan di dalam water bath pada suhu konstan $25^{\circ} \mathrm{C}$ selama 30 menit.Piknometer diangkat dari water bath lalu dikeringkan, dan ditimbang.Berat sampel diperoleh dengan menghitung selisih berat piknometer berisi sampel dan berat piknometer kosong.

Densitas dapat dihitung dengan persamaan berikut :

$$
\frac{W 1}{W 2} \times \rho \text { water }
$$

\section{Keterangan :}

$$
\begin{aligned}
\mathrm{W} 1 & =\text { Berat sampel minyak }(\mathrm{g}) \\
\mathrm{W} 2 & =\text { Berat aquades }(\mathrm{g}) \\
\rho \text { water } & =\text { Densitas air }(1 \mathrm{~g} / \mathrm{ml}
\end{aligned}
$$




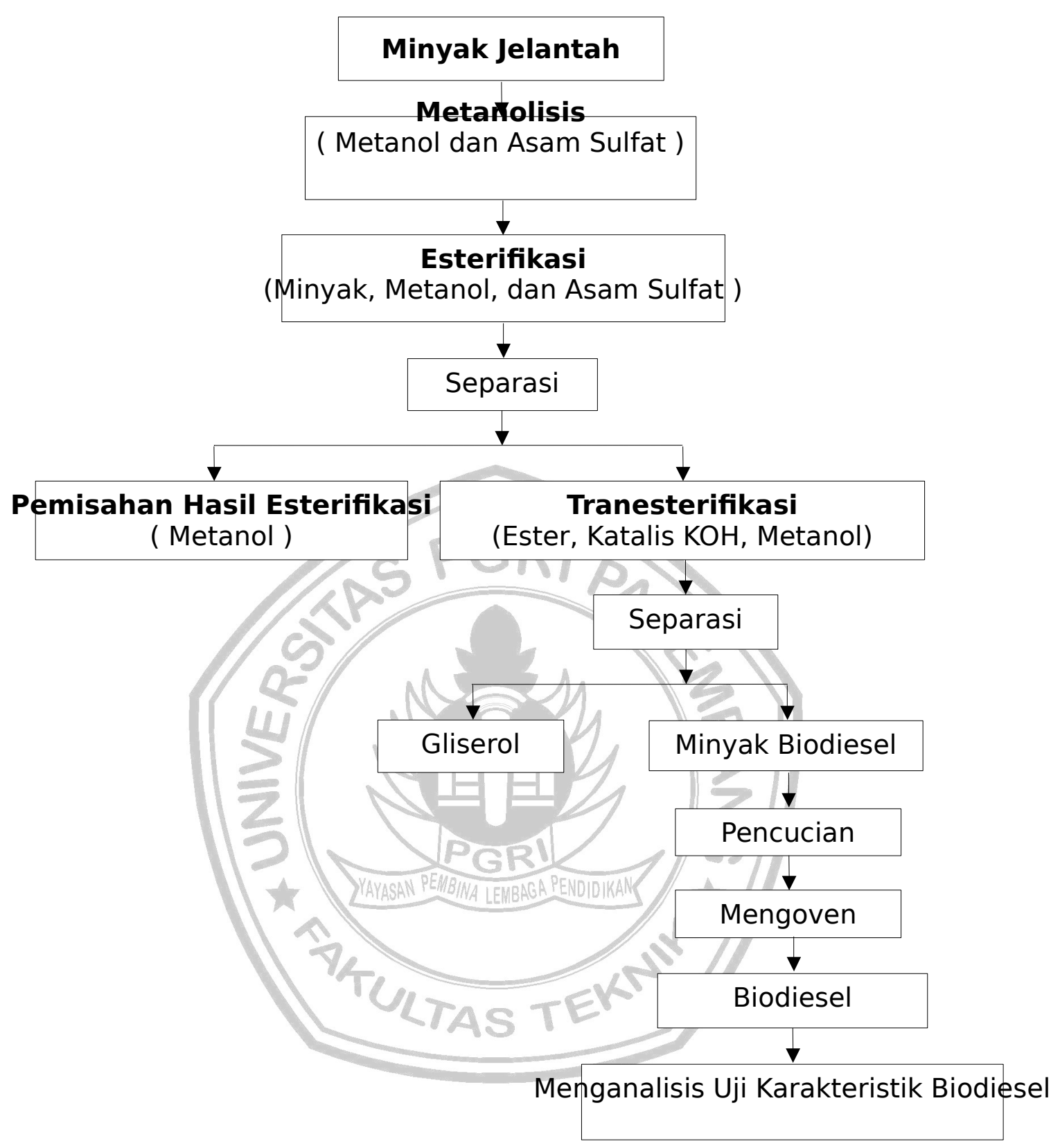

Gambar.2 Diagram AlirRancangan Penelitian

\section{HASIL DAN PEMBAHASAN}

Tabel 2 Hasil Analisis Biodisel

\begin{tabular}{|c|c|c|c|c|c|c|}
\hline \multirow{2}{*}{ No. } & \multirow{2}{*}{ Nama } & \multirow{2}{*}{ Minyak (gr) } & \multirow{2}{*}{$\begin{array}{c}\text { KOH } \\
\mathbf{( \% w t ~ o i l ) ~}\end{array}$} & FFA (\%) & AA (\%) & Densitas (g/ml) \\
\hline 1 & & & & & & \multicolumn{3}{|c|}{ Biodisel Analysis } \\
\hline 2 & Sampel 1 & 100 & 1 & 0,60 & 0.89 & 0.891 \\
\hline 3 & Sampel 2 & 100 & 2 & 0,43 & 0.67 & 0.872 \\
\hline 4 & Sampel 3 & 100 & 3 & 0,34 & 0.53 & 0.867 \\
\hline
\end{tabular}




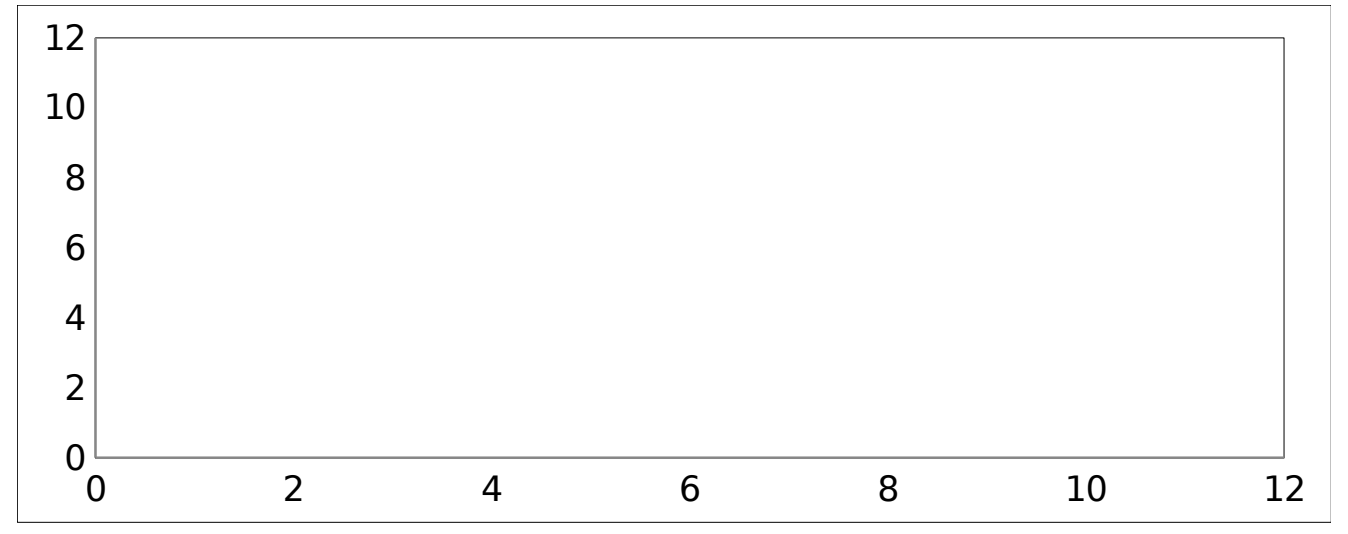

Gambar 3. Hubungan \% KOH terhadap \% FFA yang terbentuk

Pada Gambar 3 Hasil Analisa FFA dilihat bahwa nilai FFA dengan pengaruh perbedaan penambahan katalis mempengaruhi hasil Analisa FFA. Semakin banyak jumlah katalis maka nilai FFA semakin kecil dilihat pada hasil sampel 4 dengan penambahan katalis $4 \%$ berat sampel didapat nilai FFA $0,2 \%$, dibandingkan sampel 1 nilai FFA $0,60 \%$, nilai FFA $0,43 \%$ dan nilai FFA $0.34 \%$. hal ini dikarenakan dalam pembuatan biodisel menggunakan Minyak Jelantah Limbah Rumah Makan sebagai bahan baku telah ditemukan bahwa kandungan asam lemak bebas masih cukup tinggi untuk melakukan reaksi metanolisis, sebelum reaksi dilakukan, persentase asam lemak bebas dalam minyak jelantah telah dikurangi dengan mengkonversi Asam Lemak Bebas (FFA) menjadi ester melalui reaksi esterifikasi. Rasio molar metanol dengan minyak adalah 18:1, lalu ditambahkan ke 100 gr minyak dan $3 \%$ asam sulfat $\left(\mathrm{H}_{2} \mathrm{SO} 4\right)$ dari berat minyak. Esterifikasi dilakukan dengan pemanasan konvensional selama 1 jam pada suhu $50^{\circ} \mathrm{C}$ (Buathip $\mathrm{T}$ et al, 2013).

\section{Analisa Angka Asam}

Tingginya nilai angka asam dapat membuat masalah baru untuk produk biodisel. Menurut Diaz dan Galindo (2007), bahan bakar mesin diesel yang ideal adalah bahan bakar dengan rantai hidrokarbon yang sepenuhnya jenuh. Jumlah asam yang dimiliki biodisel dari minyak jelantah juga rendah, ini berarti biodisel mengandung asam lemak bebas yang sangat sedikit.Dengan demikian, biodisel tidak bersifat korosif dan tidak merusak injektor mesin diesel.Dari gambar 4. Hubungan $\% \mathrm{KOH}$ terhadap \%Angka Asam yang terbentuk dapat menyimpulkan analisa angka asam dengan perbedaan jumlah penambahan katalis menyebabkan penurunan pada jumlah katalis yang lebih banyak, seperti pada Sampel 4 nilai AA 0,27\%, sedangkan Sampel 1 nilai AA 0,89\%, Sampel 2 nilai AA 0,67 dan Sampel 3 nilai AA 0,53\%. 


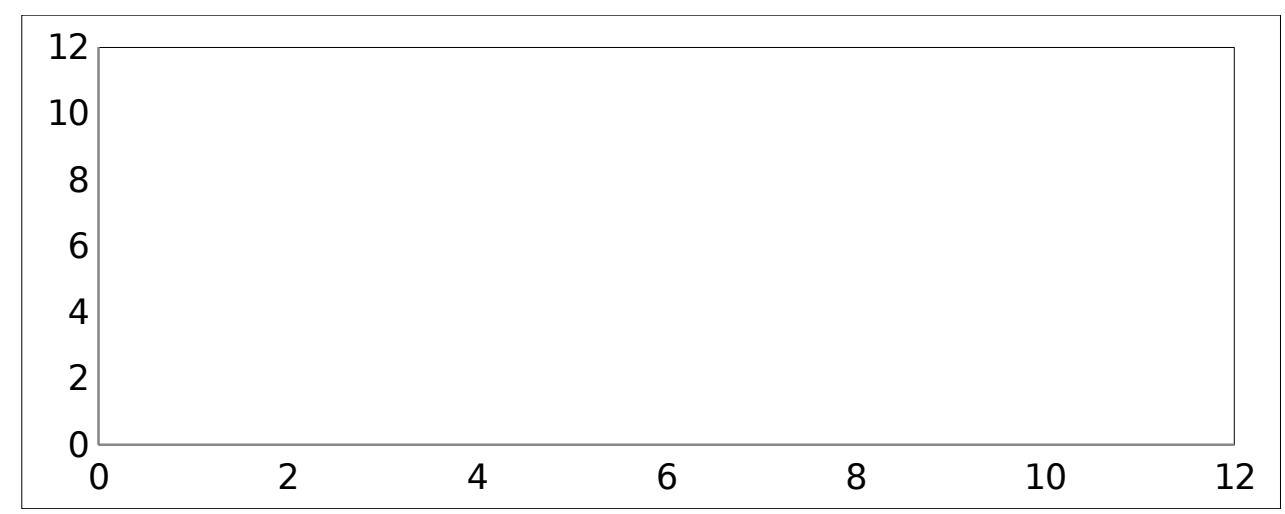

Gambar 4. Hubungan \% KOH terhadap \% Angka Asam yang terbentuk

\section{Analisa Densitas Biodisel}

Densitas adalah perbandingan massa zat pada volume tertentu dengan temperatur. Semakin rendah suhu, sehingga densitas biodisel akan lebih tinggi dan sebaliknya. Kehadiran gliserol dapat mempengaruhi nilai densitas dalam biodisel, karena gliserol memiliki densitas yang cukup tinggi $(1,26$ $\mathrm{g} / \mathrm{cm} 3$ ). Jadi jika gliserol tidak terpisah baik dari biodisel, densitas biodisel akan meningkat. Densitas biodisel dalam percobaan ini dapat dilihat pada tabel 2. Densitas standar Eropa EN-12414 memiliki persyaratan minimum adalah $860 \mathrm{~kg} / \mathrm{m} 3$ dan maksimum adalah $900 \mathrm{~kg} / \mathrm{m} 3$, katalis dalam kondisi ini tidak mempengaruhi hasil secara signifikan.

Menurut Prihandana et al., (2006), densitas biodisel yang melebihi ketentuan akan membuat reaksi pembakaran tidak sempurna. Dengan demikian dapat meningkatkan emisi dan membuat mesin diesel cepat rusak.Biodisel dengan densitas $860 \mathrm{~kg} / \mathrm{m} 3$ dapat menghasilkan pembakaran sempurna.

Dari Gambar 5 Hubungan \% KOH terhadap Densitas $(\mathrm{gr} / \mathrm{ml}$ ) yang terbentuk menyimpulkan analisa Densitas dengan perbedaan jumlah penambahan katalis menyebabkan penurunan pada jumlah katalis yang lebih banyak, seperti pada Sampel 4 Densitas diperoleh 0,859\%, sedangkan Sampel 1 Densitas diperoleh $0,891 \%$, Sampel 2 Densitas diperoleh $0,872 \%$ dan Sampel 3 Densitas diperoleh $0,867 \%$.

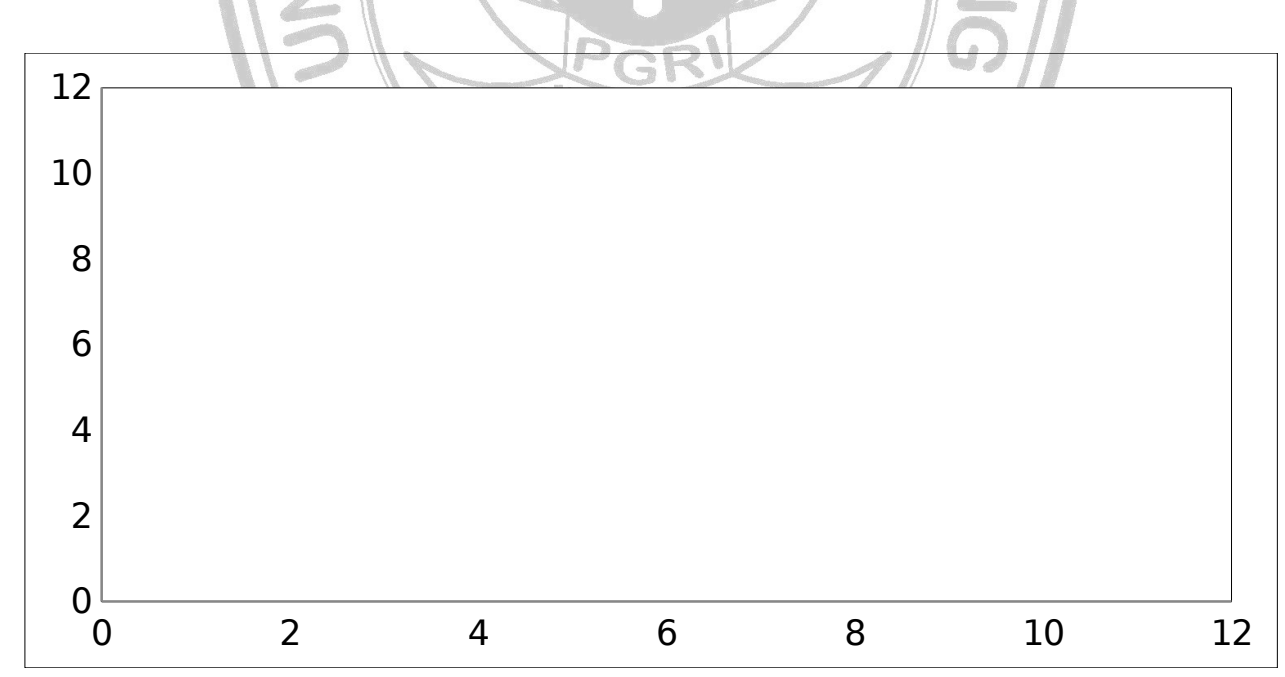

Gambar 5 Hubungan \%KOH terhadap Densitas (gr/ml) yang terbentuk

\section{KESIMPULAN}

- Variasi penambahan katalis mempengaruhi nilai FFA dan Angka Asam yang didapat biodiesel, semakin banyak katalis nilai FFA dan AA biodiesel akan semakin kecil. 
- Variasi penambahan katalis mempengaruhi nilai densitas yang didapat biodiesel, semakin banyak katalis maka densitas yang diperoleh akan lebih kecil.

- Dari variasi berbagai katalis $\mathrm{KOH}$, diperoleh bahwa kondisi optimum untuk penelitian ini adalah 4\% katalis dari berat minyak.

\section{DAFTAR PUSTAKA}

Aziz. Ismail, “Kinetika Reaksi Transesterifikasi Minyak Goreng Bekas”.Jurnal Sains dan Teknologi.

Berrios M, Siles J A, Martín M A, Martín A 2007. A kinetic study of the esterification of FFA in sunflower oil. Fuel 86, 2383-8.

Haryahto, Bode., 2002. Bahan Bakar Alternatif Biodiesel, Jurusan Teknik Kimia Universitas Sumetera Utara: USU digital library.

I Gusti Bagus Laksana,I Ketut Dunia,I Wayan Bagia.Analisis Kelayakan Bisnis bio diesel dari minyak jelantah di tinjau dari aspek finansial.

Prakoso, Tirto, 2003, Potensi Biodisel Indonesia. Laboratorium Termofluida dan Sistem Utilitas, Departemen Teknik Kimia ITB, Bandung.

Prihandana R., Hendroko R. \& Nuramin M. 2006.Menghasilkan Biodisel Murah Mengatasi Polusi danKelangkaan BBM.Jakarta: PT. Agromedia Pustaka.

Reddy, C., Reddy, V., Oshel, R., Verkade, J.G., 2006.Room-temperature conversion of soybean oil and poultry fat to biodisel catalyzed by nanocrystalline calcium oxides. Energy and Fuels $20,1310-1314$.

Romano SD, González Suárez E, Laborde MA (2006) Biodiesel. In Combustibles Alternativos, 2nd edn. Ediciones Cooperativas, Buenos Aires.

Slette, J. P., and I. E. Wiyono. 2011. Oilseeds and products update 2011. USDA Foreign Agricultural Service, Washington,D.C.,USA.

Suirtita, IW. 2009."Preparasi Biodiesel dari Minyak Jelantah Kelapa Sawit".Jurnal Sains danTeknologi ISSN 1907-9850.

Yulia,Putri.2011.Pembuatan Biodiesel dari Minyak Jelantah Melalui Proses Transesterifikasi dengan menggunakan $\mathrm{CaO}$ Sebagai Katalis.

Van Gerpen, J., 2004., "Biodiesel Production Technology”, National Renewable Energy Laboratory, U.S. Department of Energy, Research Report.

Zhang, Y., M.A. Dube, D.D. McLean, M.Kates, 2003, "Biodiesel Production from Waste Cooking, Internet conference on material flow analysis of IntegratedBio-Systems. 


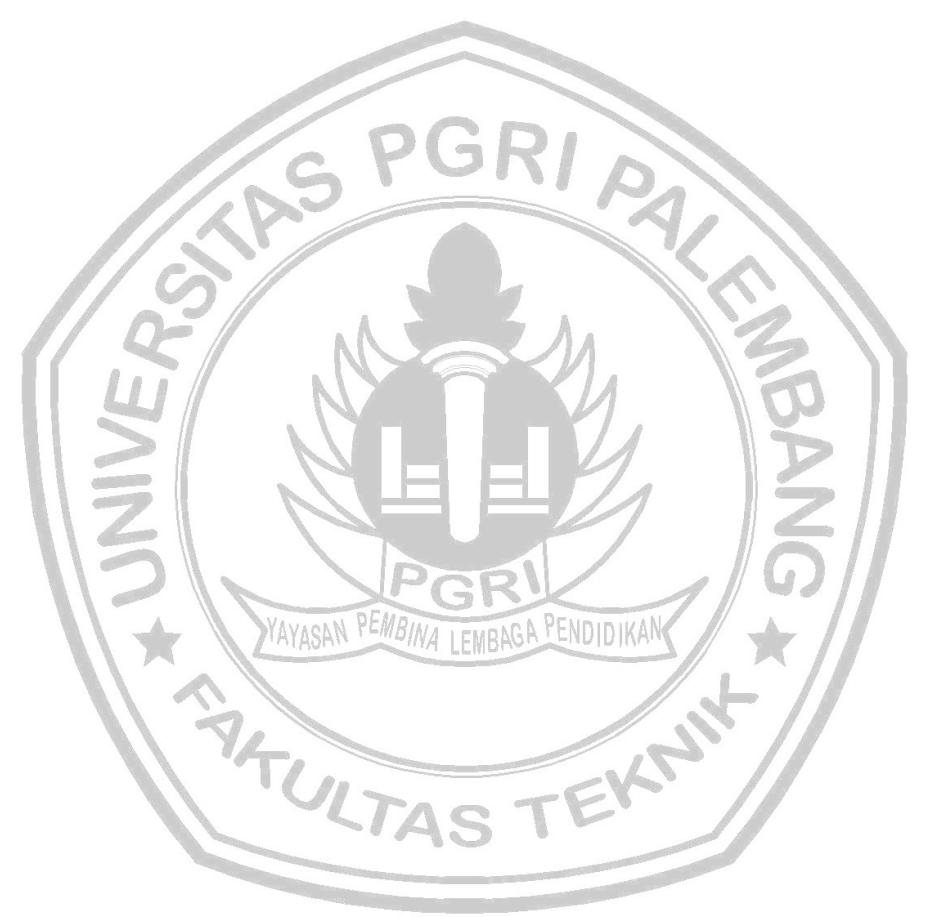

